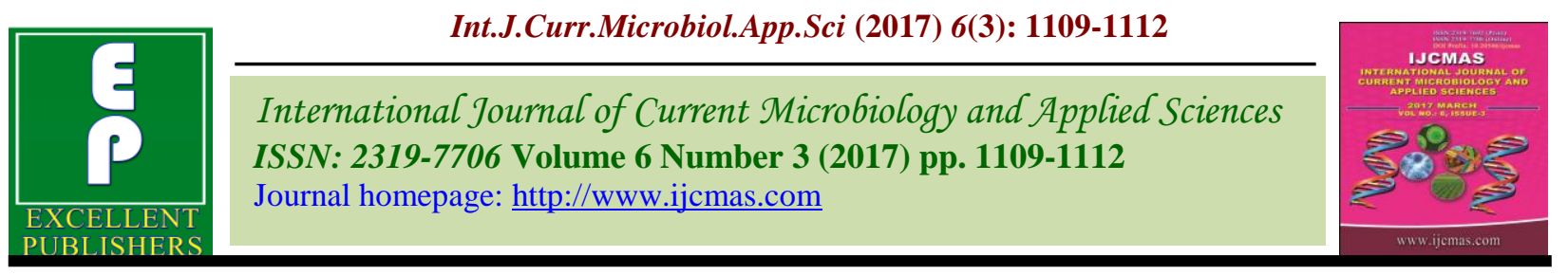

Original Research Article

https://doi.org/10.20546/ijcmas.2017.603.128

\title{
Relationship between Personal Profile and Management Orientation of Gerbera Growers
}

\author{
J.M. Deshmukh*, V.G. Dhulgand and S.N. Wanole \\ College of Agriculture, Latur, V.N.M.K.V., Parbhani, India \\ *Corresponding author
}

\begin{tabular}{|c|c|}
\hline & A B S T R A C T \\
\hline Keywords & \multirow{4}{*}{$\begin{array}{l}\text { The present study was conducted mainly with the objective to study the relationship } \\
\text { between personal profile and management orientation of gerbera growers. For the study, } \\
\text { Osmanabad, Nanded and Latur district was selected purposively from Marathwada region. } \\
\text { As regard with all independent variables viz., age, education, experience in gerbera } \\
\text { cultivation, land holding, area under gerbera, annual income, extension contact, mass } \\
\text { media exposure, risk orientation, innovativeness and economic motivation had positive } \\
\text { and highly significant relationship with their management orientation. Regarding multiple } \\
\text { regression it was found that, co-efficient of determination }\left(\mathrm{R}^{2}\right) \text { of the independent variables } \\
\text { was } 0.6241 . \text { It means that } 62.41 \text { per cent of total variation in the management orientation of } \\
\text { gerbera growers was explained by the all selected independent variables }\end{array}$} \\
\hline $\begin{array}{l}\text { Gerbera, } \\
\text { Floriculture, } \\
\text { Management } \\
\text { orientation. }\end{array}$ & \\
\hline Article Info & \\
\hline $\begin{array}{l}\text { Accepted: } \\
18 \text { February } 2017 \\
\text { Available Online: } \\
10 \text { March } 2017\end{array}$ & \\
\hline
\end{tabular}

\section{Introduction}

Farmers all over the world work as managers of their farms. Irrespective of the economic, social, cultural, physical and technological environment, the farmer manages a production system to get a return from it. In the field of agriculture too, there has been a growing awareness that only a part, perhaps a very small part, of the differences in farm income and productivity can be explained by the differences in quality and quantity of land, labour and capital. The rest of the variation has been explained mainly by the management factor. It is, therefore, observed that some farmers obtain distinctively higher yields and income than others for the same level of resources available on the farm. Floriculture is a fast emerging and highly competitive industry. With the continuous introduction of new cultivars and new crops, cultural techniques are changing and hence new products are being developed. The science and art of commercial floriculture has been recognized as an economic activity with the potential for generating employment and earning valuable foreign exchange. Floriculture being a highly investment oriented enterprise it requires an efficient and effective management in order to get high economic returns over a consistent period. Based on these perspectives, the present study was under taken with the objectives to study the relationship between profile and management orientation of gerbera growers. This study was taken to know the contribution of independent variables in deciding the dependent variable, management orientation. 
The main objective of the study is to reveal the relationship between profile and management orientation of gerbera growers.

\section{Materials and Methods}

The study was conducted in Osmanabad, Nanded and Latur district of Marathwada region of Maharashtra state. Two talukas from each district were selected purposively based on the maximum area under gerbera. Two villages from each talukas were selected purposively based on the maximum area under gerbera crop. Thus twelve villages from six talukas were selected for this study. From each of the selected village Ten gerbera growers were selected randomly on the basis of management orientation. Thus a total of 120 respondents were selected as sample for this study. The Ex-post facto research design was used in the present study. The data were collected through personal interview method with the help of pretested structured schedule consisting of various items concern with the objective of study. The farmer was contacted personally at their home during their leisure time.

\section{Results and Discussion}
Relational analysis between profile and management orientation of gerbera growers

\section{Relationship between profile of gerbera growers and management orientation}

The findings pertaining to the management orientation revealed that all independent variables viz., age, education, experience in gerbera cultivation, land holding, area under gerbera, annual income, extension contact, mass media exposure, risk orientation, innovativeness and economic motivation had positive and highly significant relationship with their management orientation (Table 1).

Table.1 Relationship between profile of gerbera growers and management orientation

$\mathrm{N}=120$

\begin{tabular}{|l|l|l|}
\hline Sr. No. & Variables & Correlation Coefficient \\
\hline 1. & Age & $0.303^{* *}$ \\
\hline 2. & Education & $0.359^{* *}$ \\
\hline 3. & Experience in gerbera cultivation & $0.338^{* *}$ \\
\hline 4. & Land holding & $0.434^{* *}$ \\
\hline 5. & Area under gerbera & $0.341^{* *}$ \\
\hline 6. & Annual income & $0.404^{* *}$ \\
\hline 7. & Extension contact & $0.541^{* *}$ \\
\hline 8. & Mass media exposure & $0.260^{* *}$ \\
\hline 9. & Risk orientation & $0.523^{* *}$ \\
\hline 10. & Innovativeness & $0.543^{* *}$ \\
\hline 11. & Economic motivation & $0.424^{* *}$ \\
\hline$* *=$ Significant at 0.01 level of probability. &
\end{tabular}


Table. 2 Correlation coefficient between components of management orientation of gerbera grower with their management orientation

\begin{tabular}{|l|l|l|}
\hline Sr. No. & Components & Correlation Coefficient (r) \\
\hline 1 & Planning orientation & $0.509^{* *}$ \\
\hline 2 & Production orientation & $0.620^{* *}$ \\
\hline 3 & Marketing orientation & $0.620^{* *}$ \\
\hline
\end{tabular}

** Significant at 0.01 level of probability.

Table.3 Multiple regression analysis between profile of gerbera growers and their management orientation

\begin{tabular}{|l|l|l|l|l|}
\hline Sr. No. & Variables & $\begin{array}{l}\text { Regression } \\
\text { Coefficients }(\mathbf{B})\end{array}$ & $\begin{array}{l}\text { Standard } \\
\text { Error (SE) }\end{array}$ & 't' value \\
\hline 1. & Age & 0.038 & 0.017 & $2.245^{*}$ \\
\hline 2. & Education & 0.230 & 0.110 & $2.078^{*}$ \\
\hline 3 & Experience in gerbera cultivation & 0.0325 & 0.065 & $0.500 \mathrm{NS}$ \\
\hline 4. & Land holding & 0.443 & 0.160 & $2.758^{*}$ \\
\hline 5. & Area under gerbera & 0.028 & 0.365 & $0.077 \mathrm{NS}$ \\
\hline 6. & Annual income & 0.157 & 0.107 & $1.469 \mathrm{NS}$ \\
\hline 7. & Extension contact & 0.128 & 0.046 & $2.764^{*}$ \\
\hline 8 & Mass media exposure & 0.060 & 0.056 & $1.075 \mathrm{NS}$ \\
\hline 9. & Risk orientation & 0.246 & 0.110 & $2.222 *$ \\
\hline 10. & Innovativeness & 0.244 & 0.080 & $3.053 * *$ \\
\hline 11. & Economic motivation & 0.167 & $2.198 *$ \\
\hline
\end{tabular}

Relationship between components of management orientation of gerbera growers with their management orientation

During research it was found that, all the components of management orientation viz., planning orientation, production orientation and marketing orientation of gerbera farmers are positively and highly significant relationship with their management orientation (Table 2).

Multiple regression analysis between profile of gerbera growers and their management orientation

By calculating the multiple regressions it was found that, co-efficient of determination $\left(\mathrm{R}^{2}\right)$ of the independent variables was 0.6241.It means that 62.41 per cent of total variation in the management orientation of gerbera growers was explained by the all selected independent variables. Also it was observed that, amongst independent variable of farmers, six variable viz., age, education, land holding, extension contact, risk orientation and economic motivation was statistically positively significant and one variable viz., innovativeness were found to be positively and highly significant. The contribution of other independent variables namely experience in gerbera cultivation, area under gerbera, annual income and mass media exposure were found to be positively non significant with management orientation of gerbera growers (Table 3 ). 


\section{References}

Birajdar, V.M. 2012. A study on management efficiency of cut flower growers. Ph.D Thesis UAS, Dharwad.

Manivannan and Hema Tripathi. 2007. Management orientation of dairy Entrepreneur. Indian Res. J. Extn.Edun., 7(2\&3): 44-51.

Prabhu, S. 2006. A study on management orientation and economics performance of chrysanthemum growers in north Karnataka, M. Sc. (Agri.), Thesis, UAS, Dharwad.

Reddy, G.K. 1983. A study of management orientation, farming efficiency and consultancy pattern of rainfed groundnut growers in Kolar district of Karnataka State, M. Sc. (Agri.) Thesis, Univ. Agric. Sci., Bangalore, Karnataka (India).

\section{How to cite this article:}

Deshmukh, J.M., V.G. Dhulgand and Wanole, S.N. 2017. Relationship between Personal Profile and Management Orientation of Gerbera Growers. Int.J.Curr.Microbiol.App.Sci. 6(3): 1109-1112. doi: https://doi.org/10.20546/ijcmas.2017.603.128 